\title{
Using Behavioural Validity Method to Analyse the Dynamic Model of Smallholder Beef Farming Systems in Indonesia
}

\author{
Novie Andri Setianto ${ }^{1)}$, Donald Cameron ${ }^{2)}$, John Gaughan ${ }^{2)}$ \\ 1) Faculty of Animal Science, University of Jenderal Soedirman, Jl. dr. Suparno Purwokerto 53123 Indonesia \\ ${ }^{2)}$ University of Queensland, Australia \\ Corresponding author email: novie.setianto@unsoed.ac.id
}

\begin{abstract}
Smallholders beef farming is a complex systems which has wide range of stakeholders whose interests are varied. Systems thinking is one approach which can be recommended to study the complexity of a system. Model is developed to mimic the situation of the farming situation in the real world. A model opens up possibilities for simulating an intervention easier, less dangerously, and more ethically than experimenting in the real world. However, before a model were used to simulate any intervention strategy, it needs to be validated. This paper aimed to describe one validity method which used to test the validity of a model describing the smallholder beef farming. A series of surveys have been undertaken to harness perspectives, opinion, and data from 2 beef farmers group in Kabupaten Banjarnegara and Kabupaten Banyumas. Model were developed using iThink software developed by Ventana ${ }^{\circledR}$. Behavioural validity was conducted using extreme condition test which use 4 combination of extreme value; calving interval, share to farmer, purchasing price, and selling price. Result showed that behavioural validity method using extreme value test was able to show the consistency of the logic which construct he structure of the model.
\end{abstract}

Key words: model validity, smallholder, beef farming, systems thinking, extreme condition test

Abstrak. Usaha peternakan sapi potong skala kecil merupakan sebuah system yang kompleks. Banyak pihak yang terlibat dalam system tersebut. Masing-masing pihak memiliki tujuan dan kepentingan yang berbedabeda. Pendekatan yang sebaiknya dilakukan ketika mempelajari sebuah system yang kompleks adalah menggunakan systems thinking. Model, yang merupakan salah satu luaran dari systems thinking, dibuat untuk mensimulasikan kondisi yang terjadi sebenarnya. Penggunaan model dianggap lebih etis, lebih mudah, dan lebih aman untuk melakukan simulasi dari skenario-skenario yang dirancang untuk meningkatkan performa system. Namun demikian, sebelum digunkan sebagai alat simulasi, sebuah model harus melalui tahap uji validitas. Artikel ini bertujuan untuk menggambarkan satu metode validasi model, yakni menggunakan behavioural method. Serangkaian survey sudah dilakukan terhadap 2 kelompok peternak sapi potong di Kabupaten Banjarnegara dan Kabupaten Banyumas untuk berdiksusi dengan peternak tentang struktur hubungan yang ada di dalam model. Model disusun menggunakan software iThink yang dikembangkan oleh Ventana ${ }^{\circledR}$. Uji validitas yang digunakan dalam behavioural method ini menggunakan uji nilai ekstrim. Terdapat 4 pasang nilai ekstrim yang diujikan, yakni selang beranak, bagian peternak, harga beli, dan harga jual. Berdasarkan hasi uji diketahui bahwa behavioural method dapat digunakan untuk menguji validitas model peternakan sapi perah rakyat. Model menunjukkan konsistensi yang logis sehingga dapat digunakan sebagai instrumen untuk mensimulasikan strategi pengembangan.

Kata kunci: uji validitas model, peternak skala kecil, systems thinking, uji nilai ekstrim

\section{Introduction}

One of the characteristics of smallholders is that the proportion of income from beef farming is usually less than $30 \%$ (Kusnadi, 2008). Most smallholders have fewer than four cattle. Farmers collect grass only when they do not have sufficient rice straw, or when rice straw becomes scarce (Hadi et al., 2002). Cut and carry is the most common feeding practice. The animal are kept mostly in housing, which frequently poorly designed and maintained (Lisson et al., 2010), for the whole year and feed is carried by hand to the cattle. In some way, smallholder farmers are systems thinkers because farmers have to balance many different 
aspects (Snapp and Pound, 2008). The farmers represent a "living pool of knowledge", and their views and knowledge could be a genuinely valuable input to strategies for reforming the smallholder beef farming sector.

Efforts to model smallholder beef farming systems in Indonesia has been undertaken by (Setianto et al., 2014a; 2014b; 2014c) which presented the qualitative Causal Loop Diagram model of smallholders. A model opens up possibilities for simulating an intervention easier, less dangerously, and more ethically than experimenting in the real world (Jackson, 2002). Modelling provides possibilities to preview whether or not the proposed changes in the systems thinking world can improve the problematic situation in the real world (Rodríguez-Ulloa et al., 2011).

One important step on model development is model validation which represents the degree of the quality of a model (Schwaninger and Groesser, 2009). The aim of the model validation is to improve the confidence that the model mimics the real situation well enough for its intended purposes thus provides a sound basis for decision making (Qudrat-Ullah, 2012; Sterman, 2000). This paper aimed to present the behavioural validity methods to analyse the model of smallholder beef farming systems.

\section{Materials and Method}

This study took place in Kabupaten Banjarnegara and Banyumas as the pilot study of two smallholders beef farmers group. The study were mostly using direct observation, semi structured interview, and focus group discussion. There are five steps involved in conducting SD methodology: (1) structuring the problem; (2) discovering the causal structure; (3) developing the dynamic model; (4) scenario simulation; and (5) implementation and organizational learning (Maani and Cavana, 2007; Sterman, 2003).

First step was to identify the qualitative Causal Loop Diagram of smallholder beef farming systems and its Systems Archetypes (Setianto et al., 2014b). Then, both the CLD and the archetypes were refined in a small group discussion which involved the representatives of actors in the system. This was achieved by contrasting the CLD with the real world situation. Some adjustments and modifications were made to ensure that the loops and linkages made sense and were able to mimic the real farming situation. Once the was CLD was regarded as being adequately capable of describing the real world situation, the next step was transforming the CLD into stocks and flows modelling to generate the dynamic model of the smallholder beef farming.

Translating the CLD into quantitative Stock and Flow dynamic model requires three steps of activity. First step was to build the model structure. This was conducted using iThink software by Ventana ${ }^{\circledR}$ systems. Second step was to parameterize data. In order to obtain all required data for the model, secondary data study has been carried out. Further, the secondary data was confronted to the model. Any data gap, which did not sufficiently filled by secondary data, need to be collected using primary data collection. Last, the stock and flow dynamics model was then need to be validated.

This study used behavioural validity tests (Barlas, 1989, 1996; Schwaninger and Groesser, 2009) examinig two components the model behaviour is valid; that its ability to mimic the major pattern exhibited by the real system and its structure has no major error. For this purpose, this study used the extreme condition test (Sterman, 2000).

\section{Results and Discussions}

\section{Stock and Flow dynamic model}

In system dynamics, modelling is described in term of stocks and flows diagrams, which show stocks, flows, auxiliary, and feedback loops (Sterman, 2000). Principally, model building transforms the flows into levels, rates and 
auxiliary variables (Rodriguez-Ulloa and PaucarCaceres, 2005). The purpose of this stage is to generate a computer-based model which is able to track all the relationships between variables, as well as their dynamic behaviour (Lane and Oliva, 1998).

A stock is symbolized by a rectangle. It means accumulations. These could be inventory, population, level of knowledge, etc. Stock will continue to exist in the system even when there is no single flow exists. Stocks visualize the state of the system. Flows are represented by an arrow pipe. An arrow pointing into a stock indicates an inflow, while pointing out of a stock denotes an outflow. Flow describes change that happens to the stock during certain period of time. Flows have regulators, known as valves, which control the flow rate. Another important symbol is clouds, which represent the sources and sinks of a flow.

The stock and flow model was build based on a translation of qualitative CLD model which has been published previously (Setianto et al., 2014). The complete translation of the model presented in Figure 1.

\section{Extreme condition test}

As the reference point, the current base situation of the smallholder beef farming system is presented in Figure 2 which describes how four stocks in the model; breeding, fattening, group capital, and farmers' income are dynamically changed. The breeding and fattening stock represents the number of breeding cows and fattening cattle in the population, whereas the group capital and farmers' income stock stand for the revenue earned from the sales for group and farmers.

With the current value, all stocks are decreasing. The low calving rate provoked farmers to shift the breeding operation into fattening. In the first 12 months, its figure increased due to program regulation which specifically mandated farmers to keep their breeding cattle. However, after 12 months without calving, many breeding cattle were culled into fattening operations. Then, after two years, all other stocks decreased as well. The revenue from sales, after deducted for farmers' share, could not sufficiently buy the same amount of cattle for the replacement stock. As a result, the number of cattle, income and capital decreased over time. There was one small increase in farmers' incomes and group capital as a result of the increasing sales of culled breeding. Also, the farmers' income decreased slightly after 48 months of simulation. This reflects how farmers tended to increase their share as the revenue from sales dropped far below their expectations. Within the based simulation, after nine years all stock would have a zero value.

To test whether the model have been able to rigorously mimic the reality, the extreme condition were applied. For this purposes, four extremes values were applied; calving rate, share for farmers, purchase price, and selling price. Details of the values presented in Table 1. Then, using these extreme values, the model was run to simulate the dynamics of the selected four stocks (breeding, fattening, farmers' income, and group capital) for the period of 120 months. Starting with the calving rate, Figure 3 and 4 showed the behaviour under low and high calving rates. Both results were as predicted. Low calving rate (Figure 3) provoke farmers to directly cull their cows, as a result, the breeding population vanished. The only remaining cows in the first 10 month (less than 3 cows) were there because the model was equipped with the order that the breeding portion should be maintained for at least 10 months. Revenue from breeding sales was used to buy more fattening cattle, thus increasing the fattening population during year 1 .

Higher calving rate (Figure 4) means more newborn calves per year; thus an increase in the population. Moreover, with a high calving rate, farmers had more interest in maintaining their breeding cattle. Consequently, more fattened 
Novie Andri Setianto/Animal Production. 18(1):43-50, January 2016

Accredited by DGHE No. 81/DIKTI/Kep./2011. ISSN 1411-2027

cattle were also available, thus more were sold resulting in increased revenue. Figure 4 describes how the calving interval of 1 (1/year) results in an increase and maintenance of the group capital, farmers' income, and the breeding and fattening population over time. It has the potential to be increased further, but the population was limited by the forage carrying capacity. These outputs were consistent with the logic of the base model.

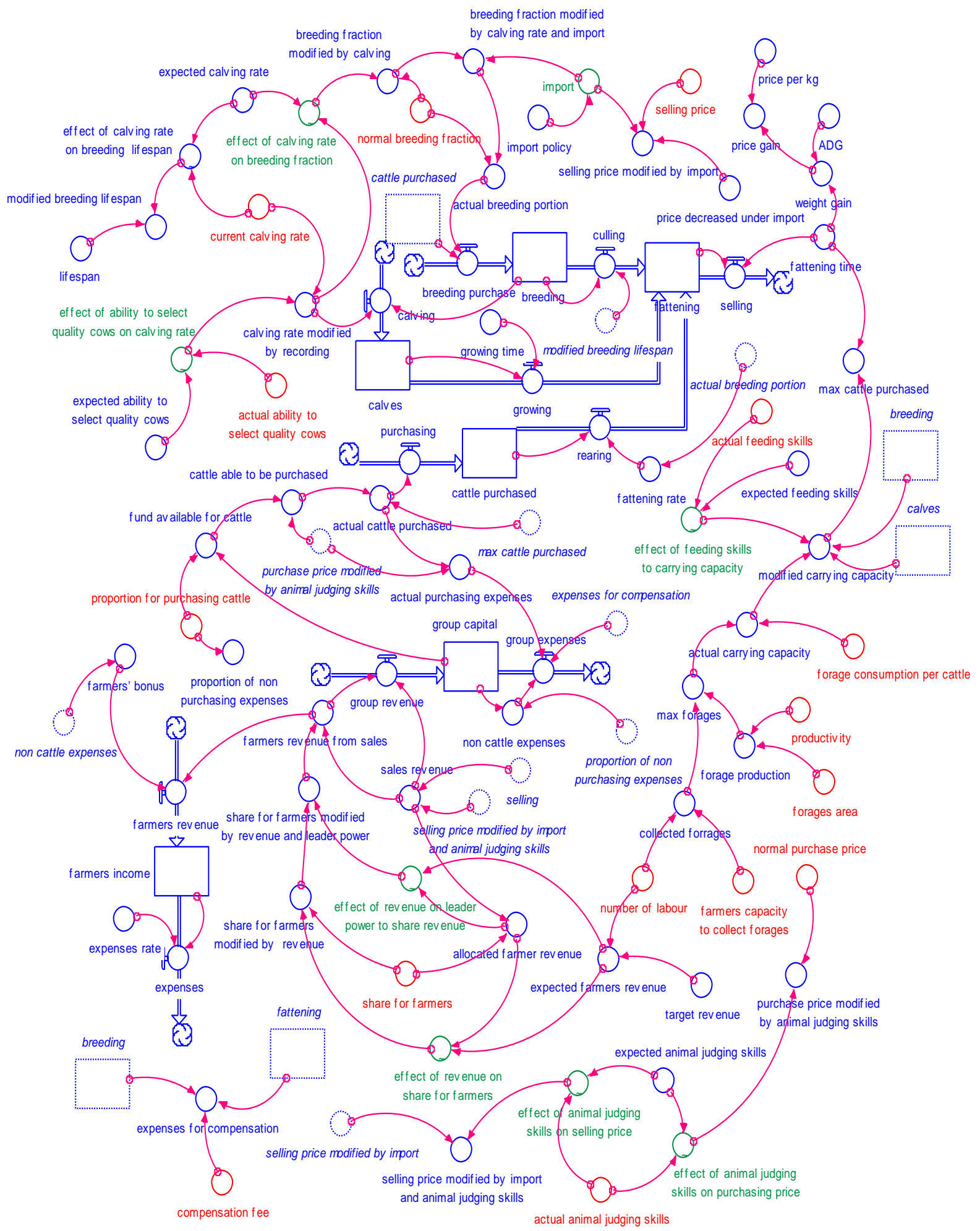

Figure 1. Stock and flow model of the smallholder beef faming system 
Table 1. Extreme values for simulations

\begin{tabular}{lcccc}
\hline Variable & Base value & Minimum & Maximum & Unit \\
\hline Calving rate & 0.5 & 0.1 & 1 & $1 /$ year \\
Share for farmers & 10 & 1 & 50 & $\%$ \\
Purchase price & 6.5 & 3.25 & 13 & Rp/cattle \\
Selling price & 8.25 & 4.125 & 16.5 & Rp/cattle \\
\hline
\end{tabular}

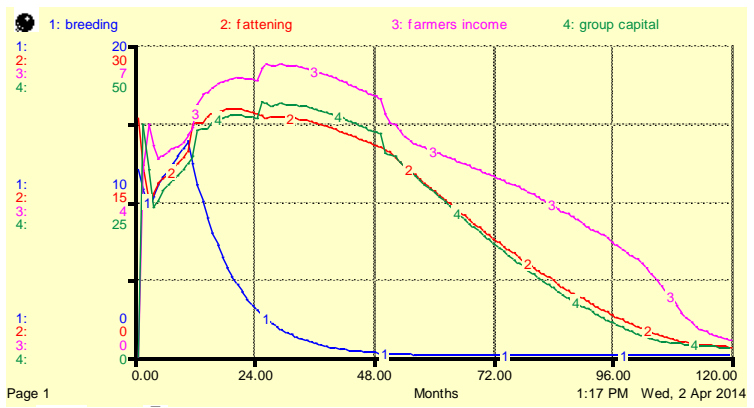

Figure 2. Base condition of the model running 120 months simulations

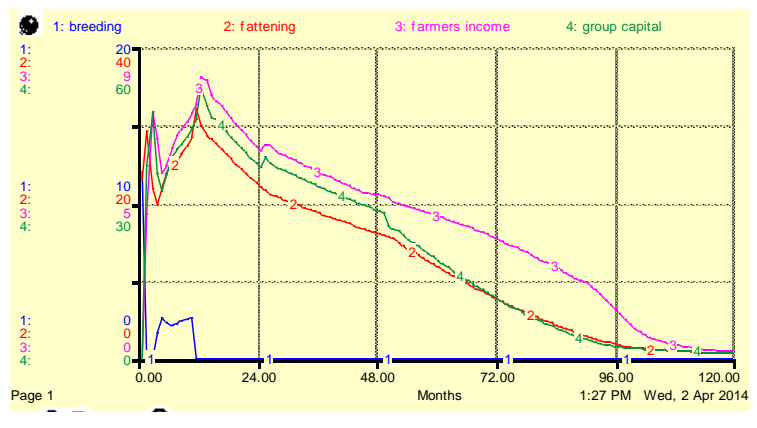

Figure 3. Low extreme calving rate

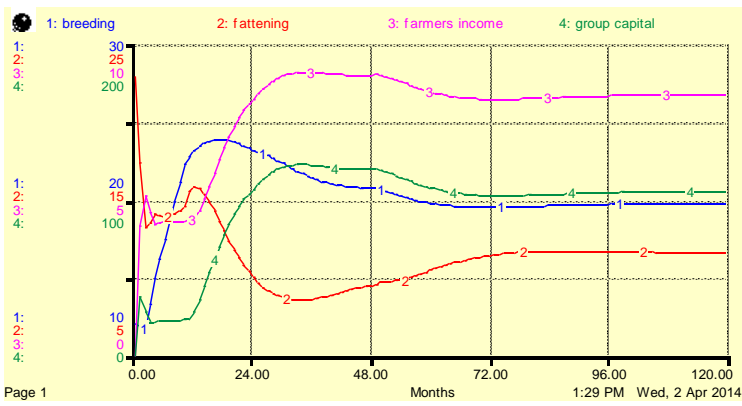

Figure 4. High extreme calving rate

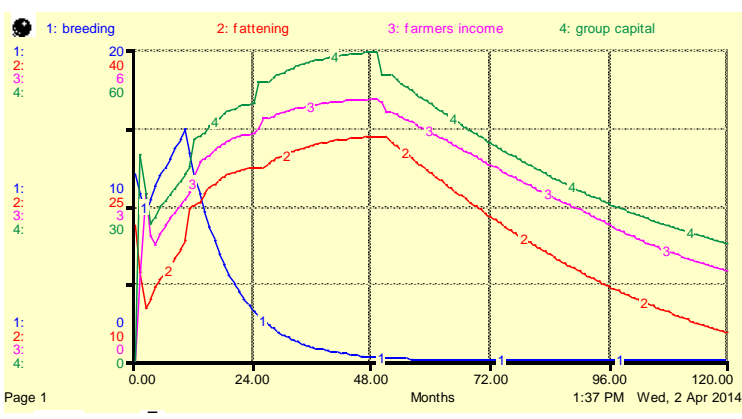

Figure 5. Low extreme share for farmers

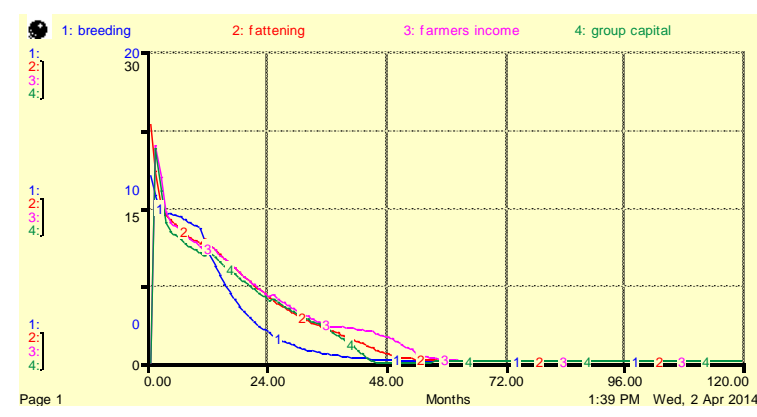

Figure 6. High extreme share for farmers

The model was then run using the extreme condition of the share for farmers. Ten percent of the sales revenue was allocated for farmers' shares and the remaining $90 \%$ was allocated for the group to cover costs for purchasing replacement cattle and other group expenses. Under a low extreme condition, the model is able to perform a rational simulation. As shown in Figure 5, fewer shares went to the farmers which meant more shares were available for the group. This would result in the maintenance of farming for a longer period compared with the current base condition. However, over the first 48 months, farmers' incomes were lower than the base. More of the group shares can therefore be used to buy more cattle, thus the population is higher than the base before it decreases due to the selling price dropping as a result of the import policy after month 48 . In contrast, high extreme share allocation to farmers (Figure 6) will mean that most of the sales revenue went to the farmers' household and less was allocated for reinvestment in the farm. 
Lastly, the model was run using the price extreme, both for purchasing and selling price. For purchasing price, the lower extreme occurs when the purchasing price was set to be halved from Rp6.5 million to Rp3.25 million/animal. In contrast the extreme high use assumption was that the price was doubled to $\mathrm{Rp} 13$ million/animal. Figure 7 showed that except for breeding, all stocks were sustained. With lower purchasing prices, farmers managed to yield more profit. This is shown by the increase in farmers' incomes, the number of fattened cattle and the group capital over time.

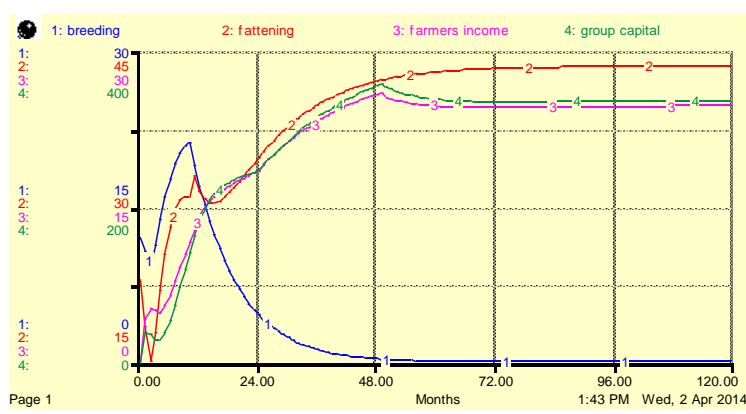

Figure 7. Low purchasing price

After 72 months, the system was in equilibrium. Although the group capital was sufficient to buy more cattle, the carrying capacity of maximum 44 cattle meant that the cattle population peaked. In contrast, Figure 8 showed that when the model is exposed to a high purchasing price, farmers failed to obtain profit and suffered significant losses. As a result all stocks decline significantly and essentially vanish after year four when no capital is left to purchase cattle. These results indicate that the model used is able to mimic the real condition.

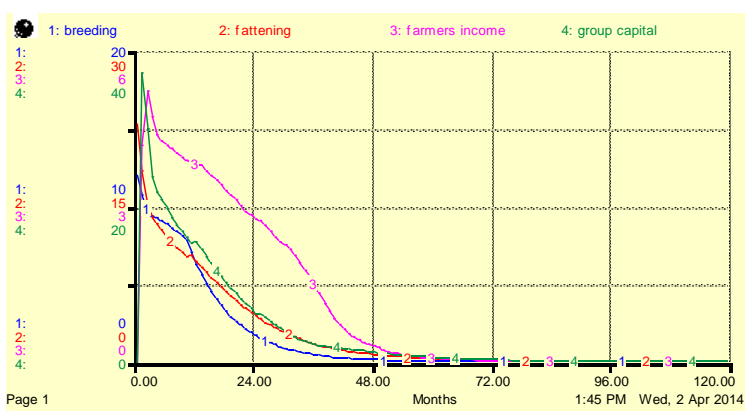

Figure 8. High purchasing price
The low selling price was simulated using half of the current selling price. Subsequently, the high selling price is double of the current price. Figure 9 displays how the stock behaves when the selling price is halved. Beef farming would be non-existent after the fourth year. However, when the selling price is doubled farming would be sustainable (Figure 10) although the breeder numbers would continue to fall due to the low calving rate. Similar to the case of low purchasing price, the population will be constrained by the carrying capacity.
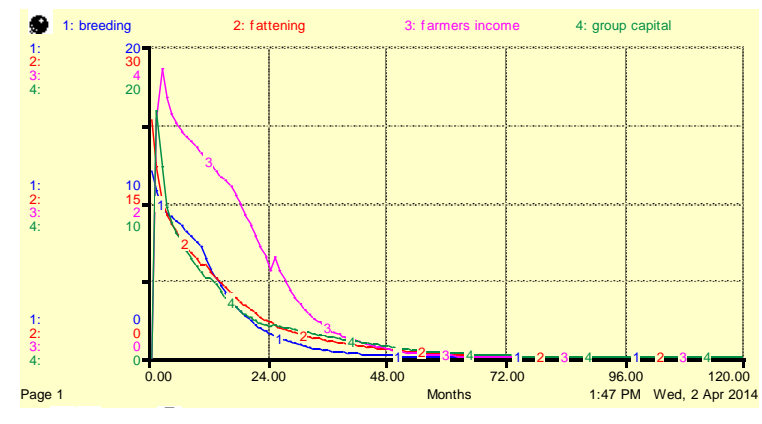

Figure 9. Low selling price

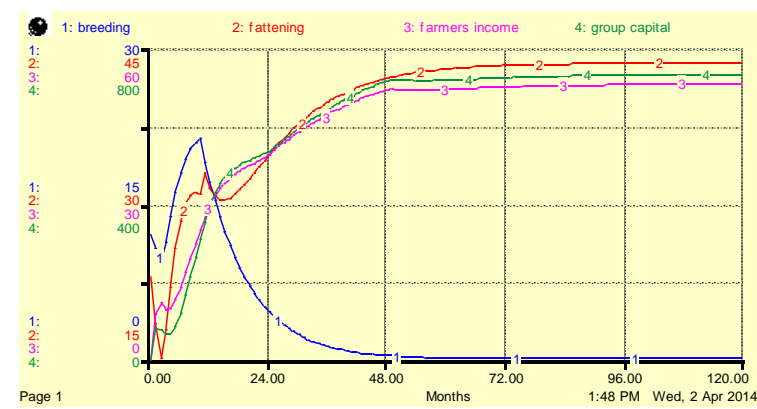

Figure 10. High selling price

The next extreme situation is the combination of the selling and purchasing prices. Firstly, the model was run using low selling and purchasing price. Purchasing price was halved to Rp3.250 million, whereas the selling price was Rp4.125 million per cattle. The difference between the selling price and the purchase price is Rp875 thousand; far less than of Rp2 million used in the initial basic simulation. The output of the model (Figure 11) shows that with a low margin, all stocks decrease.

When the model used a combination of high selling and purchasing prices, the output showed 
that all stocks increased. Figure 12 shows the model output when the selling and purchasing price doubled to Rp13 million and Rp16.5 million respectively. Thus, the margin between purchasing and selling increased from $\mathrm{Rp} 2$ million to Rp3.5 million.

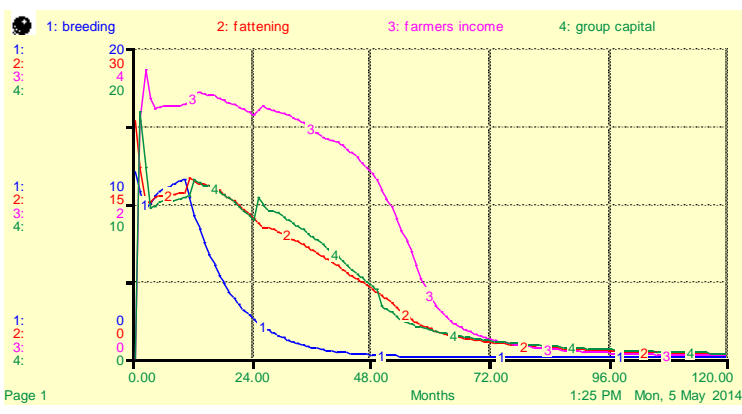

Figure 11. Low purchasing and selling price

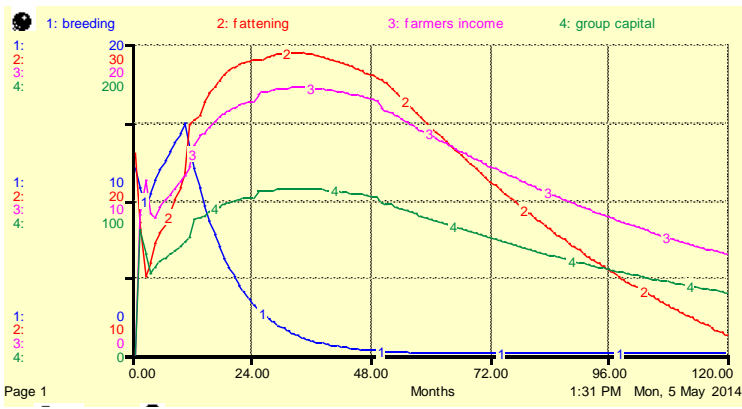

Figure 12. High purchasing and selling price

Based on the ability of the model to simulate the situations under the different extreme conditions used, this researcher believes that the model has a sound structure and is without any major structural errors.

\section{Conclusions}

The behavioural validity method could be employed to analyse the validity of a stock and flows model which model the smallholder beef farming system. Based on extreme condition test using four different combination of extreme value, the model showed its consistency to logically mimic the behavioural of the real situation of the smallholder beef farming. Thus, validated model could be used to simulate strategy simulation.

\section{References}

Barlas Y. 1989. Multiple tests for validation of system dynamics type of simulation models. European Journal of Operational Research, 42(1): 59-87. doi:http://dx.doi.org/10.1016/ 0377-2217(89)90059-3

Barlas Y. 1996. Formal aspects of model validity and validation in system dynamics. System Dynamics Review, 12(3): 183-210. doi: 10.1002/(sici)1099-1727(199623)12:3 $<183$ ::aid-sdr103>3.0.c0;2-4

Hadi PU, N Ilham, A Thahar, B Winarso, D Vincent and D Quirke. (2002) Improving Indonesia's beef industry. ACIAR Monograph. Canberra: Australian Center for International Agriculture Research (ACIAR).

Jackson MC. 2002. Systems Approaches to Management. New York, Boston, Dordrecht, London, Moskow: Kluwer Academic Publishers.

Kusnadi U. 2008. Inovasi Teknologi Peternakan dalam Sistem Integrasi Tanaman-Ternak untuk Menunjang Swasembada Daging Sapi Pengembangan Inovasi Pertanian, 1(3): 189205.

Lane DC and R Oliva. 1998. The greater whole: Towards a synthesis of system dynamics and soft systems methodology. European Journal of Operational Research, 107(1): 214-235. doi:DOI:10.1016/s0377-2217(97)00205-1

Lisson S, N MacLeod, C McDonald, J Corfield, B Pengelly, L Wirajaswadi, L Brennan. 2010. A participatory, farming systems approach to improving Bali cattle production in the smallholder crop-livestock systems of Eastern Indonesia. Agricultural Systems, 103(7): 486497. doi:10.1016/j.agsy.2010.05.002

Maani K and R Cavana. 2007. System thinking, system dynamics; managing change and complexity. Rosedale New Zealand: Pearson education.

Qudrat-Ullah H. 2012. On the validation of system dynamics type simulation models. Telecommunication Systems, 51(2-3): 159166. doi:10.1007/s11235-011-9425-4

Rodríguez-Ulloa R, A Montbrun and S MartínezVicente. 2011. Soft System Dynamics Methodology in Action: A study of the Problem of Citizen Insecurity in an Argentinean Province. Systemic Practice and 
Novie Andri Setianto/Animal Production. 18(1):43-50, January 2016

Accredited by DGHE No. 81/DIKTI/Kep./2011. ISSN 1411-2027

Action Research, 24(4): 275-323. doi:DOI:10.1007/s11213-010-9187-z

Rodriguez-Ulloa R and A Paucar-Caceres. 2005. Soft System Dynamics Methodology (SSDM): Combining Soft Systems Methodology (SSM) and System Dynamics (SD). Systemic Practice and Action Research, 18(3): 303-334. doi:DOI:10.1007/s11213-005-4816-7

Schwaninger M and S Groesser. 2009. System Dynamics Modeling: Validation for Quality Assurance. In Meyers RA (Ed.), Encyclopedia of Complexity and Systems Science (pp. 90009014): Springer New York.

Setianto NA, D Cameron and JB Gaughan. 2014. Identifying Archetypes of an Enhanced System Dynamics Causal Loop Diagram in Pursuit of Strategies to Improve Smallholder Beef Farming in Java, Indonesia. Systems Research and Behavioral Science, 31(5): 642654. doi:10.1002/sres.2312

Setianto NA, D Cameron and JB Gaughan. 2014. Structuring the problematic situation of smallholder beef farming in Central Java, Indonesia: using systems thinking as an entry point to taming complexity. International Journal of Agricultural Management, 3(3): 164-174.

Setianto NA, DC Cameron and JB Gaughan. 2014. Everyday Flux of Smallholder Beef Farming: System Overview of the Beef Farming Situation Under a Government Grant. Animal Production, 16(1): 39 - 47.

Snapp S and B Pound. 2008. Agricultural Systems: Agroecology and Rural Innovation for Development Retrieved from http://UQL.eblib.com.au/patron/FullRecord. aspx? $\mathrm{p}=802408$

Sterman JD. 2000. Business Dynamics: System Thinking and Modelling for A Complex World. New York: Irwin McGraw-Hill.

Sterman JD. 2003. Learning in and about Complex Systems. In Midgley G (Ed.), Systems Thinking (Vol. III). London - Thousand Oaks New Delhi: SAGE Publications. 